\title{
PREFERENSI NYAMUK AEDES AEGYPTI PADA BEBERAPA MEDIA AIR
}

\author{
${ }^{1}$ Antje A. Wuwungan \\ ${ }^{2}$ Saartje J. Lumanauw \\ ${ }^{3}$ Jimmy Posangi \\ ${ }^{2}$ Odi R. Pinontoan
}

\author{
${ }^{1}$ Bagian Anestesiologi dan Terapi Intensif Fakultas Kedokteran Universitas Sam Ratulangi \\ Manado \\ ${ }^{2}$ Fakultas Pertanian Universitas Sam Ratulangi Manado \\ ${ }^{3}$ Bagian Farmakologi Fakultas Kedokteran Universitas Sam Ratulangi Manado \\ Email: antjewuwungan@yahoo.com
}

\begin{abstract}
The Aedes aegypti mosquitoes are the main vectors of Dengue virus which causes Dengue Fever and Dengue Haemorrhagic Fever. Their blood sucking activity occurs during the day and they rest inside houses (endophagic and anthropophilic). Ae. aegypti females prefer to lay eggs in man-made containers. The purpose of this study was to determine the habitat and development of Ae. aegypti in four types of water (rain water, well water, tap water, and soap water). The method of this study was random group design. The results showed that Ae. aegypti prefered black containers to white containers. Conclusion: The preference of the Ae. aegypti mosquitos in choosing the water media for laying eggs and their development whether in rain water, well water, tap water, or soap water were not significantly different.
\end{abstract}

Keywords: Aedes aegypti, Dengue, types of water.

\begin{abstract}
Abstrak: Nyamuk Aedes aegypti merupakan vektor Dengue utama yang mejadi penyebab Demam Dengue dan DBD. Aktivitas mengisap darah terjadi pada siang hari dan nyamuk dewasa cenderung beristirahat di dalam rumah (endofagik dan antropofilik). Ae. aegypti lebih menyukai wadah buatan manusia untuk tempat berkembang biak. Tujuan penelitian ini untuk mengetahui habitat nyamuk Ae. aegypti pada empat jenis air. Metode penelitian yang digunakan yaitu metode rancangan acak kelompok. Hasil penelitian menunjukkan bahwa $A e$. aegypti lebih memilih wadah berwarna hitam dari pada wadah berwarna putih. Simpulan: Preferensi nyamuk Ae. aegypti untuk meletakkan telur pada media air hujan, air sumur, air PAM, dan air sabun tidak memperlihatkan perbedaan bermakna.
\end{abstract}

Kata kunci: Aedes aegypti, Dengue, jenis air.

Nyamuk Aedes aegypti merupakan vektor utama dengue penyebab demam dengue dan demam berdarah dengue. Nyamuk betina berperan sebagai vektor, dan mempunyai kebiasaan mengisap darah pada siang hari, antropofilik, endofagik, dan beristirahat di dalam rumah. Darah manusia yang diisap oleh nyamuk Ae. aegypti betina digunakan untuk mematangkan telur. Pada saat mengisap darah manusia, nyamuk betina akan mengeluarkan air liur bersama virus di dalamnya sehingga manusia dapat terinfeksi virus dengue. Protein di dalam darah diubah menjadi lipid dan glikogen yang berguna sebagai energi bagi nyamuk Ae. aegypti betina untuk terbang serta memperpanjang kelangsungan hidupnya. ${ }^{1}$ Setelah mengisap darah manusia, nyamuk 
Ae. aegypti beristirahat di dalam rumah untuk menunggu sampai telur matang. Oviposisi terjadi pada siang hari dengan puncak pada dua jam setelah matahari terbit dan dua jam sebelum matahari terbenam ${ }^{2}$ dan tidak terjadi pada malam hari. $^{3}$ Nyamuk meletakkan telur pada dinding wadah $1-2 \mathrm{~cm}$ di atas permukaan air, dan lebih memilih air bersih yang tidak mengalir dan wadah buatan orang.

Strickman dan Kittayapong (1993) menemukan bahwa oviposisi lebih banyak terjadi di wadah yang berada dalam rumah daripada di luar rumah. ${ }^{3}$ Surtees $(1967)^{4}$ melaporkan kira-kira $60 \%$ telur diletakkan pada wadah yang gelap dan $80 \%$ oviposisi terjadi pada suhu di bawah $30^{\circ} \mathrm{C}^{5}$ Faktor yang memengaruhi oviposisi, yaitu: jenis dan warna wadah, warna air, makanan di dalam air, suhu, dan kondisi lingkungan di sekitarnya. Wadah plastik yang berwarna hitam mengandung lebih banyak larva nyamuk Ae. aegypti daripada wadah kaca, logam, dan keramik. ${ }^{5}$ Masyarakat biasanya menggunakan wadah untuk menampung air jernih untuk keperluan sehari-hari yang diletakkan di dalam maupun di luar rumah. Air yang ditampung berasal dari air PAM, air hujan, dan air sumur; kesemuanya ini dapat menjadi tempat penting bagi $A e$. aegypti untuk meletakkan telur. ${ }^{6}$

Air dapat mengandung mikro-organisme seperti bakteri yang menjadi makanan larva. Persyaratan air bersih menurut Peraturan Menteri Kesehatan RI Nomor 416/ MENKES/PER/IX/1990 tanggal 3 September 1990 yaitu batas maksimal nilai kekeruhan 25 NTU dan batas minimum serta maksimal $\mathrm{pH} 6,5-9,0 .^{7}$ Kualitas air dan kuantitas makanan hasil proses pembusukan vegetasi di dalam air menentukan jumlah telur yang akan diletakkan oleh nyamuk betina. ${ }^{8}$ Telur terdapat lebih banyak di air yang bersih daripada yang terkontaminasi. Menurut Surtees (1967), pada air yang terkontaminasi telur dapat menetas menjadi larva dan berkembang lebih cepat menjadi imago. Ae. aegypti hinggap di dinding wadah melalui stimulus taktil untuk dapat mengetahui kualitas dan kuantitas makanan yang tersedia, sehingga dapat menentukan jumlah telur yang akan diletakkannya di setiap wadah. ${ }^{8}$

Larva Ae.aegypti dapat menyesuaikan dirinya di dalam air dengan suasana asam maupun basa tanpa terganggu kelangsungan hidupnya. Hasil penelitian Clark et al (2004) ${ }^{9}$ memperlihatkan larva Ae. aegypti dapat berkembang ketika ditempatkan di air dengan $\mathrm{pH}$ 4-11, tetapi larva selalu mati bila ditempatkan di air dengan pH 3 dan 12 . Sehgal dan Pillai (1970) ${ }^{10}$ menyatakan Ae. aegypti lebih memilih air dengan $\mathrm{pH}$ yang sedikit alkalis (basa) untuk tempat berkembang biak.

Media air telah digunakan dalam penelitian untuk tempat perkembangan nyamuk Ae. Aegypti, antara lain air PAM, air sabun mandi (Lux) dan air detergen (Rinso), ${ }^{11}$ air hujan dan air sumur, ${ }^{12}$ serta air sumur dan air PAM. ${ }^{6}$ Sudarmaja dan Mardihusodo $(2009)^{11}$ menggunakan wadah yang berisi air PAM, air sabun mandi (Lux), dan air detergen (Rinso) menunjukkan bahwa media air sabun mandi dan air PAM merupakan tempat yang dipilih oleh nyamuk $A e$. aegypti untuk meletakkan telur, menetas menjadi larva, dan berkembang sampai imago.

\section{METODE PENELITIAN}

Penelitian dilaksanakan di Kelurahan Malalayang Satu Kecamatan Malalayang Kota Manado, dimulai pada bulan September 2011 sampai dengan April 2012.

Masing-masing media air yaitu air sumur, air PAM, dan air hujan ditampung dalam wadah ember yang diletakkan di atas lantai beton pada tempat terbuka. Untuk memperoleh air sabun, sabun Lux sebanyak 0,5 gram dilarutkan dalam 1 liter air PAM.

Untuk menilai preferensi nyamuk $A e$. aegypti terhadap warna wadah digunakan wadah berwarna hitam dan putih, disediakan masing-masing empat buah diisi air hujan, air sumur, air PAM, dan air sabun, dengan tiga ulangan. Semua wadah ini diletakkan di dalam ruangan secara acak. Pengamatan dilakukan setiap hari. Pada hari ke-7 ditemukan larva dalam wadah hitam sedangkan dalam wadah putih 
tidak ada. Semua larva yang ada dalam wadah hitam diambil dengan pipet, kemudian dipindahkan ke baskom bersama air dengan jumlah yang cukup. Baskom ditutup dengan kain tile supaya tidak ada nyamuk yang datang bertelur. Perkembangan diamati setiap hari dan yang menjadi imago diambil dengan botol plastik kecil, ditutup, kemudian dimasukkan ke dalam lemari es untuk mempertahankan supaya nyamuk masih tetap utuh dan tidak terjadi perubahan warna yang memudahkan untuk identifikasi.

Nyamuk diamati melalui mikroskop cahaya dan diidentifikasi dengan menggunakan kunci identifikasi nyamuk. Tanggal dan jenis air dicatat, kemudian nyamuk betina dimasukkan kedalam lemari es untuk keperluan pemeriksaan virus dan analisis DNA melalui metode PCR.

\section{HASIL DAN BAHASAN}

\section{Preferensi nyamuk Ae. aegypti terhadap warna wadah}

Hasil penelitian menunjukkan preferensi nyamuk Ae. aegypti pada media air dengan warna wadah (Tabel 1).

Tabel 1. Jumlah imago betina Ae. aegypti berdasarkan warna wadah dan jenis air

\begin{tabular}{llcc}
\hline $\begin{array}{c}\text { Warna } \\
\text { wadah }\end{array}$ & Jenis air & $\begin{array}{c}\text { Jumlah } \\
\text { imago } \\
\text { (ekor) }\end{array}$ & $\begin{array}{c}\text { Rerata } \\
\text { (ekor) }\end{array}$ \\
\hline Hitam & Air hujan & 22 & 5,5 \\
& Air sumur & 28 & 7,0 \\
& Air PAM & 14 & 3,5 \\
& Air sabun & 10 & 2,5 \\
Putih & Air hujan & 0 & 0 \\
& Air sumur & 0 & 0 \\
& Air PAM & 0 & 0 \\
& Air sabun & 0 & 0 \\
\hline
\end{tabular}

Tabel 1 memperihatkan bahwa imago betina Ae. aegypti memilih wadah-wadah berwarna hitam yang berisi keempat jenis air untuk meletakkan telurnya, sedangkan wadah berwarna putih tidak. Warna wadah merupakan salah satu daya tarik bagi imago betina Ae. aegypti untuk meletakkan telur.
Ae. aegypti memilih warna berdasarkan visual dan nyamuk ini tertarik pada warna hitam. $^{13}$ Menurut Chua et al (2004), ${ }^{8}$ permukaan wadah yang berwarna gelap merupakan atraktan jarak jauh untuk $A e$. aegypti betina.

Pada penelitian ini ditemukan hal yang sama dimana Ae. aegypti betina tertarik untuk warna hitam karena ditemukan larva yang berkembang sampai imago dalam wadah berwarna hitam sedangkan yang berwarna putih tidak ada. Ae.aegypti lebih tertarik pada warna hitam sejalan dengan penelitian Venzani dan Schweigmann (2002) ${ }^{5}$, yang menemukan lebih banyak larva dalam wadah berwarna hitam; mosquito traps yang dilapisi kartu perekat warna hitam lebih banyak mengandung nyamuk Ae.aegypti yang tertangkap daripada alat penangkap nyamuk lainnya. ${ }^{14}$ Peneliti lain melaporkan nyamuk dewasa lebih banyak terdapat dalam wadah berwarna hitam daripada yang putih. $^{8}$ Pada penelitian ini tidak ditemukan larva atau imago dalam wadah berwarna putih karena Ae aegypti hanya tertarik pada wadah hitam. Hal ini mungkin disebabkan karena kelimpahan Ae. aegypti saat itu rendah.

Tabel 2 memperlihatkan preferensi nyamuk Ae. aegypti pada beberapa jenis air, terlihat secara berturut-turut jumlah nyamuk $A e$. aegypti yang terdapat pada masing-masing jenis air yaitu air PAM 4,2 individu, air hujan 2,8 individu, air sumur 2,4 individu, dan air sabun 2,3 individu. Hasil analisis sidik ragam menunjukkan bahwa jenis air tidak memberikan perbedaan bermakna terhadap jumlah nyamuk $A e$. aegypti pada wadah berwarna hitam. Hasil analisis ini mengindikasikan bahwa semua jenis air dapat menjadi tempat berkembang biak nyamuk Ae. aegypti.

Larva dapat berkembang sampai imago, terkait dengan makanan di dalam wadah yang dapat menjadi makanan larva. Berdasar hal ini larva dapat berkembang menjadi imago di keempat jenis air dalam wadah hitam; dengan demikian semua jenis air dapat dijadikan tempat berkembang biak nyamuk $A e$. aegypti. Menurut penelitian 
Surtess (1967), ${ }^{4}$ Ae. aegypti lebih memilih air bersih untuk oviposisi. Larva hidup terutama di air bersih untuk keperluan air minum. ${ }^{15}$ Hasil penelitian ini menunjukkan bahwa wadah hitam yang berisi air hujan, air sumur, serta air PAM menjadi tempat berkembang biak Ae. aegypti.

Wadah hitam yang berisi air sabun dapat juga menjadi tempat berkembang biak nyamuk Ae aegypti sesuai dengan penelitian Sudarmaja dan Mardihusodo (2009) dimana air PAM dan air sabun merupakan media tempat peletakan dan penetasan telur serta perkembangan larva Ae. aegypti. ${ }^{11}$ Air sabun mungkin mengandung bahan organik tumbuhan untuk makanan larva Ae. aegypti. Hasil analisis keempat jenis air yaitu air PAM, air sumur, air sabun dan air hujan dapat dilihat pada Tabel 3.

Analisis air dengan parameter turbiditas (kekeruhan) yang tertinggi yaitu air sabun 449 NTU, diikuti air sumur 2,6 NTU, air hujan 1 NTU, dan yang terendah air PAM 0,5 NTU. Parameter $\mathrm{pH}$ yang tertinggi yaitu air sumur 7,48, diikuti air sabun 7,18, air PAM 7,13 dan terendah air hujan 6,14. Parameter oksigen terlarut yang tertinggi yaitu air PAM 7,77 mg/l, air hujan $7,56 \mathrm{mg} / \mathrm{l}$, air sumur $7,19 \mathrm{mg} / \mathrm{l}$, dan yang terendah air sabun $5,59 \mathrm{mg} / \mathrm{l}$. Parameter chloride yang tertinggi pada air sabun 15 $\mathrm{mg} / \mathrm{l}$, air sumur $12,5 \mathrm{mg} / \mathrm{l}$, air PAM 10,9 $\mathrm{mg} / \mathrm{l}$, dan yang terendah air hujan $0,8 \mathrm{mg} / \mathrm{l}$.

Menurut Permenkes RI No 416/Menkes/Per/IX/1990 batas maksimal air bersih nilai kekeruhan 25 NTU dan batas minimum dan maksimum $\mathrm{pH}$ 6,5$9,0{ }^{7}$ Berdasar nilai $\mathrm{pH}$ dari air PAM, air sumur, dan air hujan yang berkisar 7,137,48 dan kekeruhannya berkisar 0,5-2,6 NTU termasuk air bersih karena sesuai nilai yang menjadi syarat air bersih. Hasil analisis air sabun dengan nilai kekeruhan 449 NTU jauh di atas nilai maksimal air bersih dan jauh di atas ketiga jenis air lainnya yang hanya berkisar 0,5-2,6 NTU. Air normal yang memenuhi syarat untuk suatu kehidupan berkisar 6,5-7,5.

Tabel 2. Jumlah imago betina Ae. aegypti pada setiap jenis air.

\begin{tabular}{ccccccc}
\hline Jenis air & \multicolumn{4}{c}{ Ulangan } & Jumlah & Rerata \\
\cline { 2 - 5 } & $\mathbf{1}$ & $\mathbf{2}$ & $\mathbf{3}$ & $\mathbf{4}$ & nyamuk & \\
\hline Air hujan & 15 & 5 & 21 & 4 & 45 & 2,8 \\
Air sumur & 13 & 9 & 11 & 6 & 39 & 2,4 \\
Air PAM & 11 & 9 & 10 & 38 & 68 & 4,2 \\
Air sabun & 3 & 0 & 0 & 34 & 37 & 2,3 \\
\hline
\end{tabular}

Tabel 3. Analisis keempat jenis media air yang digunakan.

\begin{tabular}{ccccc}
\hline \multirow{2}{*}{ Parameter } & \multicolumn{4}{c}{ Analisis } \\
\cline { 2 - 5 } & Air PAM & Air sumur & Air sabun & Air hujan \\
\hline Turbiditas & $0,5 \mathrm{NTU}$ & $2,6 \mathrm{NTU}$ & $449 \mathrm{NTU}$ & $1 \mathrm{NTU}$ \\
$\mathrm{pH}$ & 7,13 & 7,48 & 7,18 & 6,14 \\
Oksigen terlarut & $7,77 \mathrm{mg} / \mathrm{l}$ & $7,19 \mathrm{mg} / \mathrm{l}$ & $5,59 \mathrm{mg} / 1$ & $7,56 \mathrm{mg} / \mathrm{l}$ \\
Chloride & $10,9 \mathrm{mg} / \mathrm{l}$ & $12,5 \mathrm{mg} / \mathrm{l}$ & $15 \mathrm{mg} / \mathrm{l}$ & $0,8 \mathrm{mg} / \mathrm{l}$ \\
\hline
\end{tabular}

Air limbah menurut Surat Keputusan Menteri Negara KLH Nomor Kep03/MENKLH/II/1991, tanggal Februari 1991 untuk mutu air I-III mempunyai pH 69. Air sabun dengan $\mathrm{pH} \mathrm{6,14} \mathrm{lebih} \mathrm{rendah}$ dari nilai $\mathrm{pH}$ minimum yaitu 6,5 yang ditentukan pada air bersih tetapi sesuai dengan syarat $\mathrm{pH}$ air limbah, sehingga air sabun termasuk air limbah. Hal ini menunjukkan bahwa Ae. aegypti dapat 
berkembang biak, baik di air bersih maupun di air limbah. Keempat jenis air yang mempunyai nilai parameter turbiditas, $\mathrm{pH}$, oksigen terlarut, dan chlorida dalam penelitian ini merupakan media yang baik untuk oviposisi Ae. aegypti, penetasan telur, dan perkembangan larva sampai imago.

Perilaku oviposisi dimediasi oleh visual, olfaktori, dan taktil. ${ }^{8}$ Proses pembusukan vegetasi di dalam air menghasilkan aroma bahan kimia yang dapat merupakan atraktan jarak dekat terhadap Ae. aegypti betina dan juga dapat menghasilkan makanan untuk keturunannya. ${ }^{9}$ Pembusukan mungkin dapat terjadi dari bahan-bahan di dalam air sabun. Hasil pembusukan menghasilkan aroma bahan kimia yang menarik Ae.aegypti betina menuju ke air sabun dan hinggap di dinding wadah. Selain itu, bahan-bahan tersebut dapat menjadi makanan untuk keturunannya.

Saat hinggap di dinding wadah, posisi kepala nyamuk di atas dan ovipositor di bawah, kira-kira $1 \mathrm{~cm}$ di atas permukaan air, kemudian nyamuk meletakkan telur di permukaan air sabun yang berwarna keruh (nilai kekeruhan 449 NTU). Kejadian ini menunjukkan bahwa nyamuk tidak merasakan dan tidak menilai air tersebut jernih atau keruh. Hal ini mungkin karena terdapat stimulus yang merangsang $A e$. aegypti untuk meletakkan telurnya di wadah air sabun. Menurut Chua et al (2004), ${ }^{8}$ nyamuk betina yang hinggap di dinding wadah terkait stimulus taktil atau stimulus lain dapat mengetahui kualitas dan kuantitas makanan yang tersedia, sehingga nyamuk tersebut akan meletakkan telur di wadah tersebut sesuai dengan yang diperkirakannya.

Terkait dengan air sabun yang semakin lama kekeruhannya berkurang karena partikel-pertikel sabun akan mengendap pada dasar wadah, telur yang jatuh di air sabun dapat menetas dan berkembang menjadi imago. Kenyataan larva $A e$. aegypti dapat berkembang hingga imago walaupun menurut Wardhana (2004) pH air normal yang memenuhi syarat untuk suatu kehidupan berkisar $6,5-7,5 .^{7}$ Kejadian ini mungkin karena larva Ae. aegypti dapat beradaptasi di air dalam kisaran suasana asam atau basa, dengan $\mathrm{pH} 4-11 .^{9}$

\section{SIMPULAN}

Dari hasil penelitian ini dapat disimpulkan bahwa Ae. aegypti hanya memilih wadah berwarna hitam untuk meletakkan telur. Selain itu, Ae. aegypti dapat hidup dan berkembang pada air bersih, air kotor, dan air limbah.

\section{SARAN}

Diperlukan monitoring perkembangan nyamuk Ae aegypti pada wadah-wadah air dan genangan air di sekitar lingkungan masyarakat karena ternyata nyamuk ini dapat berkembang pada setiap wadah yang berisi air.

\section{DAFTAR PUSTAKA}

1. McMeniman JC, Hughes GL, Oneill S. A Wolbachia Symbiont in Aedes aegypti disrupts mosquito egg development to a greater extent when mosquitoes feed on nonhuman versus human blood. Journal medical entomology. 2011;48(1):76-84.

2. Harringthon CL, Ponlawat A, Edman JD, Scott TW, Vermeylen F. 2008. Influence of container size, location, and time of day on oviposition patterns of the dengue vector, Aedes aegypti, in Thailand. Vector-borne and zoonotic disease. 2008;8(3):415-23.

3. Harringthon CL, Edman JD. Indirect evidence against delayed "skipoviposition" behavior by Aedes aegypti (Diptera: Culicidae) in Thailand. Journal of Medical Entomology. 2001;38:641-5.

4. Surtees G. Factors affecting the oviposition of Aedes aegypti. Bull. Wld. Health Org. 1967;36:594-6.

5. Vezzani D, Vellazques MS, Schweigmann N. Seasonal pattern of abundance of Aedes aegypti (diptera: culicidae) in Buenos Aires, Argentina. Mem. Inst. Oswaldo Cruz. 2004;99(4):351-6.

6. Mutiarawati TD. Pengaruh kadar zat-zat 
terlarut didalam air bersih terhadap perkembangan biakan nyamuk Aedes aegypti pra-dewasa. Jurnal Penelitian Kesehatan Suara Forikes. 2010;1(2):969.

7. Wardhana WA. Dampak Pencemaran Lingkungan. Yogyakarta: Penerbit Andi Yogjakarta, 2004.

8. Chua KB, Chua IL, Chua IE, Chua KH. 2004. Differential preferences of oviposition by Aedes mosquitos in man made containers under field conditions. Southeast Asean J. Trop Med Public Health. 2004;35(3):599-607.

9. Clark MT, Flis BJ, Remold SK. 2004. pH tolerances and regulatory abilities of freshwater and euryhaline Aedine mosquito larvae. The Journal of Experimental Biology. 2004;207:2297304.

10. Sehgal SS, Pillai MKK. 1970. Preliminary Studies on the Chemical Nature of Mosquito-Breeding Waters in Delhi. p. 647-50 (financed by WHO).

11. Sudarmaja IM, Mardihusodo SJ. Pemilihan tempat bertelur nyamuk Aedes aegypti pada air limbah rumah tangga di Laboratorium. Jurnal Veteriner. 2009;10(4):205-7.
12. Strickman D, Kittayapong P. Dengue and its vectors in Thailand: calculated transmission risk from total pupal counts of Aedes aegypti and association of wing-length measurements with aspects of the larval habitat. Am. J. Trop. Med. Hyg. 2003;68(2):209-17.

13. Manda H, Arce LM, Foggie T, Schal $P$, Grieco JP, Achee NL. Effect of irritant chemicals on Aedes aegypti resting behavior is there a simple shift to untreated "Safe Sites"? PloS Negl Trop Dis. 2011;5(7):e 1243.

14. De-Freitas RM, Peres RC, Alves F, Brandolini MB. 2008. Mosquito traps designed to capture Aedes aegypti (Diptera: Culicidae) females: preliminary comparison of adult trap, mosquiTRAP and backpack aspirator efficiency in a dengue-endemic area of Brazil. Mem. inst. Oswaldo Cruz. 2008;103(6). [cited: 2012 Feb 3]. Available from: http://dx.doi.org/10.1590/S007402762008000600016.

15. Service MW. Medical Entomology for Students (Second Edition). Cambridge: Cambridge University Press, 2000. 